\section{UJMM

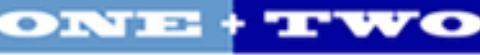

Volume 2 | 2010 Spring

\section{Undergraduate Journal of Mathematical}

Modeling: One + Two

2010

\title{
Effect of Tire Pressure on Efficiency
}

Miles Mullins

University of South Florida

Advisors:

Arcadii Grinshpan, Mathematics and Statistics

Gray Mullins, Civil \& Environmental Engineering

Problem Suggested By: Gray Mullins

Follow this and additional works at: https://digitalcommons.usf.edu/ujmm

Part of the Mathematics Commons

UJMM is an open access journal, free to authors and readers, and relies on your support:

Donate Now

\section{Recommended Citation}

Mullins, Miles (2010) "Effect of Tire Pressure on Efficiency," Undergraduate Journal of Mathematical

Modeling: One + Two: Vol. 2: Iss. 2, Article 7.

DOI: http://dx.doi.org/10.5038/2326-3652.2.2.7

Available at: https://digitalcommons.usf.edu/ujmm/vol2/iss2/7 


\title{
Effect of Tire Pressure on Efficiency
}

\begin{abstract}
Many people ignore tire pressure in their day-to-day lives. In a country striving for maximum efficiency, neglecting to maintain correct tire pressure can noticeably affect the amount of horsepower required to overcome the drag forces due to tire/roadway friction. In order to quantify these horsepower changes, 21 test trials were conducted by allowing a test vehicle to coast from $50 \mathrm{mph}$ down to $20 \mathrm{mph}$ at pressures ranging from $50 \mathrm{psi}$ to $20 \mathrm{psi}$. After compiling the results, it was shown that lower tire pressures increased the horsepower necessary to propel the automobile.
\end{abstract}

\section{Keywords}

Tire Pressure, Velocty, Horsepower

\section{Creative Commons License}

(c) (i) ()

This work is licensed under a Creative Commons Attribution-Noncommercial-Share Alike 4.0 License. 


\section{TABLE OF CONTENTS}

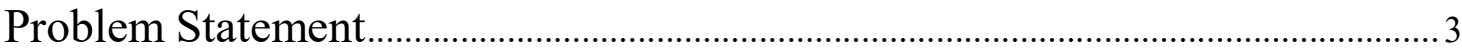

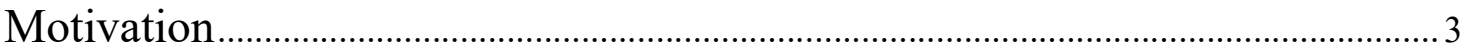

Mathematical Description and Solution Approach .....................................................

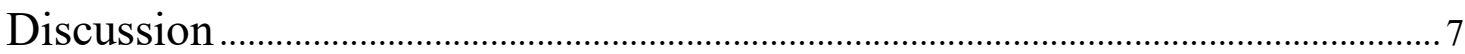

Conclusion and Recommendations ......................................................................9

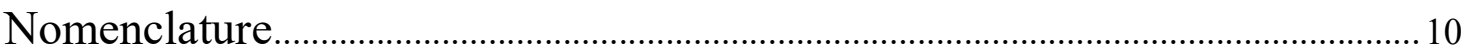

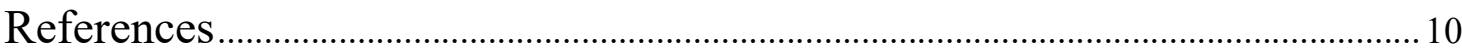

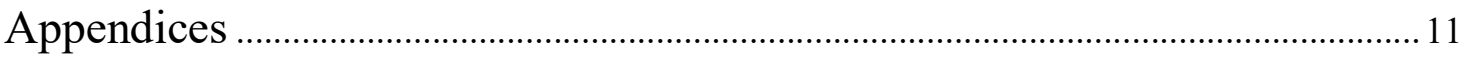




\section{PROBLEM STATEMENT}

More than ever before, the automotive world is focusing on ways to obtain higher efficiency. Many new technological advancements target power consumption, but one of the easiest ways to increase efficiency often goes ignored: the vehicle's tire pressure. The only connection between a vehicle and its driving surface is the four contact patches where the tires meet the roadway. Monitoring tire pressure and attempting to minimize the amount of rolling friction may combat energy waste. From the data collected at different tire pressures, determine if there is a difference in the efficiency of over and under inflated tires.

\section{MOTIVATION}

Modern advertisements for new cars showcase their fuel efficiency. This paradigm shift highlights the fact that automobile manufacturers are spending additional resources to engineer a more efficient vehicle. While the new technological advancements are effective, it is important implement simple techniques such as maintaining proper tire pressure to avoid wasting energy/fuel. As a tire pressure drops, the walls of the tire become soft and flexes when the wheel rotates. This deformation increases the drag and causes the vehicle to use more energy to maintain forward motion. The objective of this project is to quantify the change in the horsepower required to maintain a constant velocity based on the changes in tire pressure. We pursued this goal by collecting field data and analyzed it using calculus principles. 


\section{MATHEMATICAL DESCRIPTION AND SOLUTION APPROACH}

In this experiment, we measured the time required to slow a vehicle from $50 \mathrm{mph}$ to $20 \mathrm{mph}$ through wind resistance and tire friction. Changing only the pressure in the tires allowed us to determine the overall influence that tire pressure plays in efficiency.

There are several sources which cause drag on a car. Wind can push or pull on a car affecting the power requirements to maintain a constant velocity. The shape of a vehicle controls how well it resists drag as it passes through the air. Internally, drive train friction can differ from vehicle to vehicle. The drive train friction determines how much energy from the engine is absorbed before transferring its power to the wheel or the ground.

The tire-roadway interaction also affects the drag on a vehicle. Driving surfaces can range from dirt roads and mud to paved highways. Each driving surface can produce a very different amount of friction. Some tires are made of compounds tailored to different aspects of driving. If maximum grip is preferred, a tire manufactured from a softer compound can be used

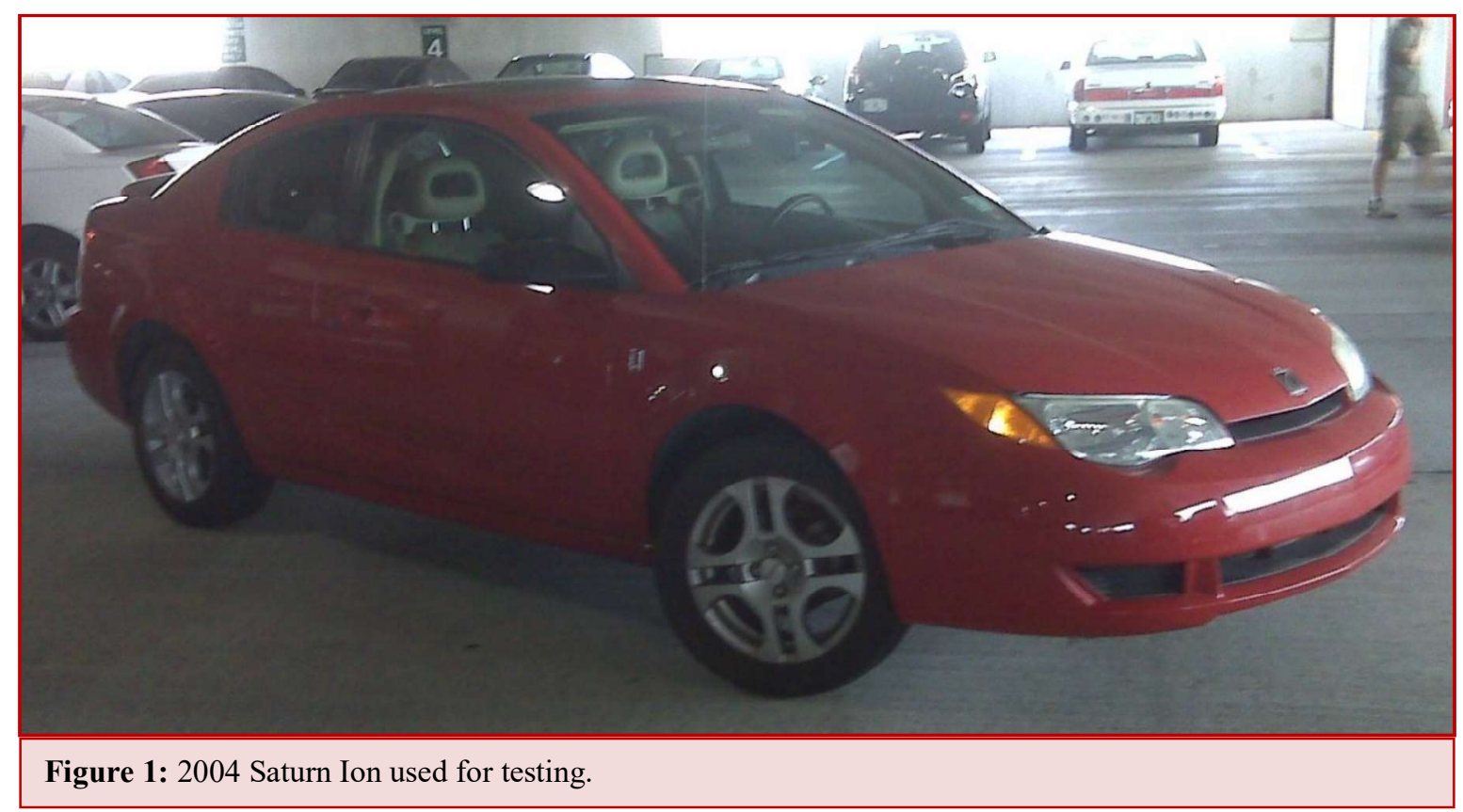


to increase grip. However, an increased grip also increases friction which in turn diminishes the efficiency of the power transfer from the tire to the ground.

\section{TESTING CONDITIONS}

Wind speed and roadway variations were controlled by conducting all tests consecutively on the same roadway (Figure 2), in the same direction, and on the same day. Also, the same vehicle (Figure 1) was used for all trials so that the vehicle aerodynamics remained constant. To exclude drive train friction, all testing and timing was done while the car was in neutral so that the transmission was not actively creating drag. These restrictions were employed to isolate the tire pressure as the sole variable governing the power required to maintain a constant velocity.

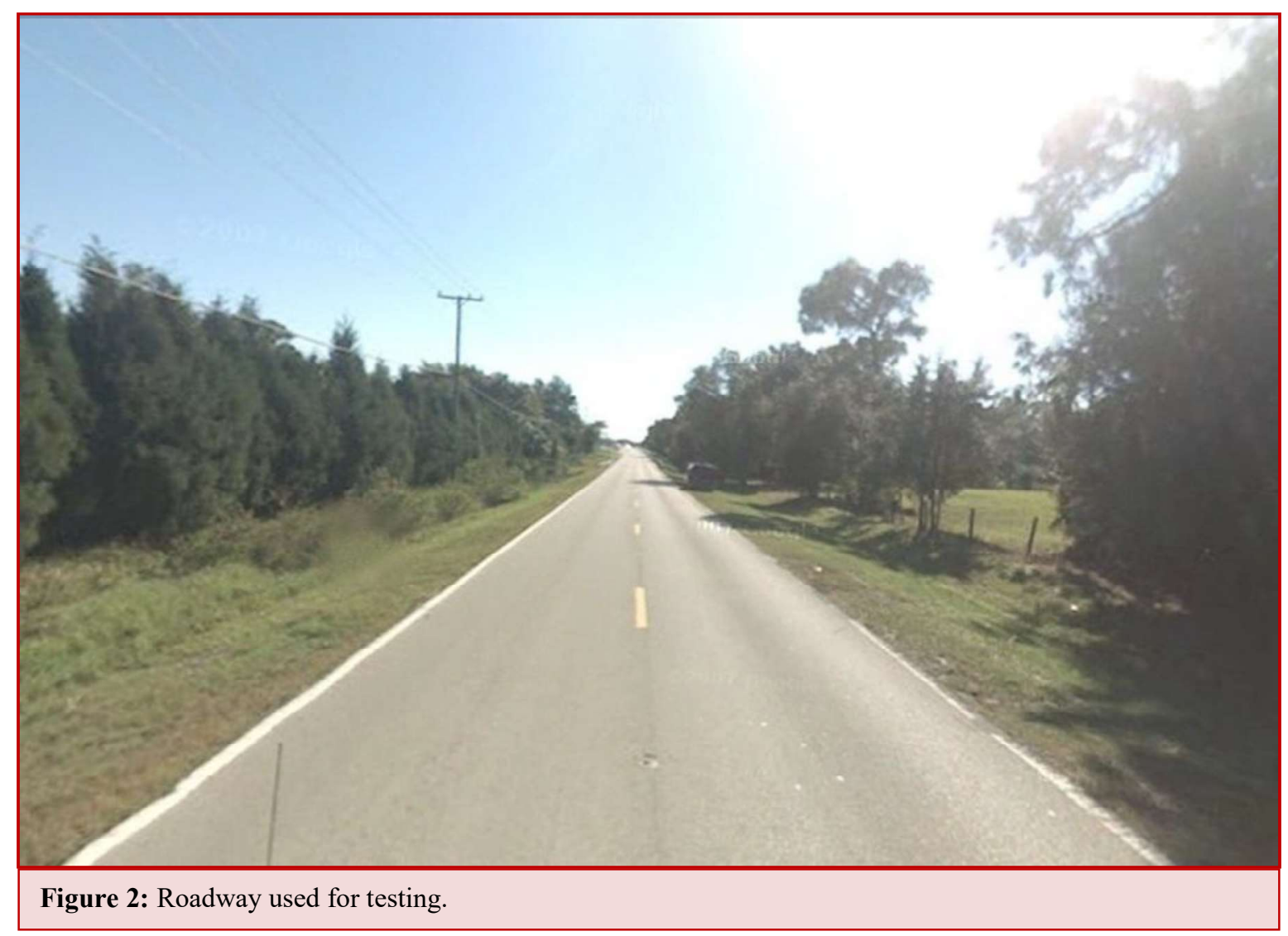




\section{DATA COLLECTION}

The recorded data was collected after pumping the tires up to a specific pressure starting at a high of $50 \mathrm{psi}$ and going down to a low of 20 psi in 5 psi increments. The test was conducted by bring the test vehicle to a velocity of $50 \mathrm{mph}$. Then at a specific location the test car was set to coast. A stopwatch with a lap button (Figure 3) was used to record how long it took the coasting vehicle to drop each 5 mile/hour increment. The results of 3 test runs (Appendix A - Table 1) were averaged for each of the tire pressures.

\section{ANALYSIS}

The velocities acquired by our tests can be used to calculate acceleration of the test vehicle (R.C. Hibbler, 19) using

$$
a=\frac{\Delta v}{\Delta t}
$$

and the displacement (R.C. Hibbler, 20) using

$$
\Delta s=\int v d t
$$

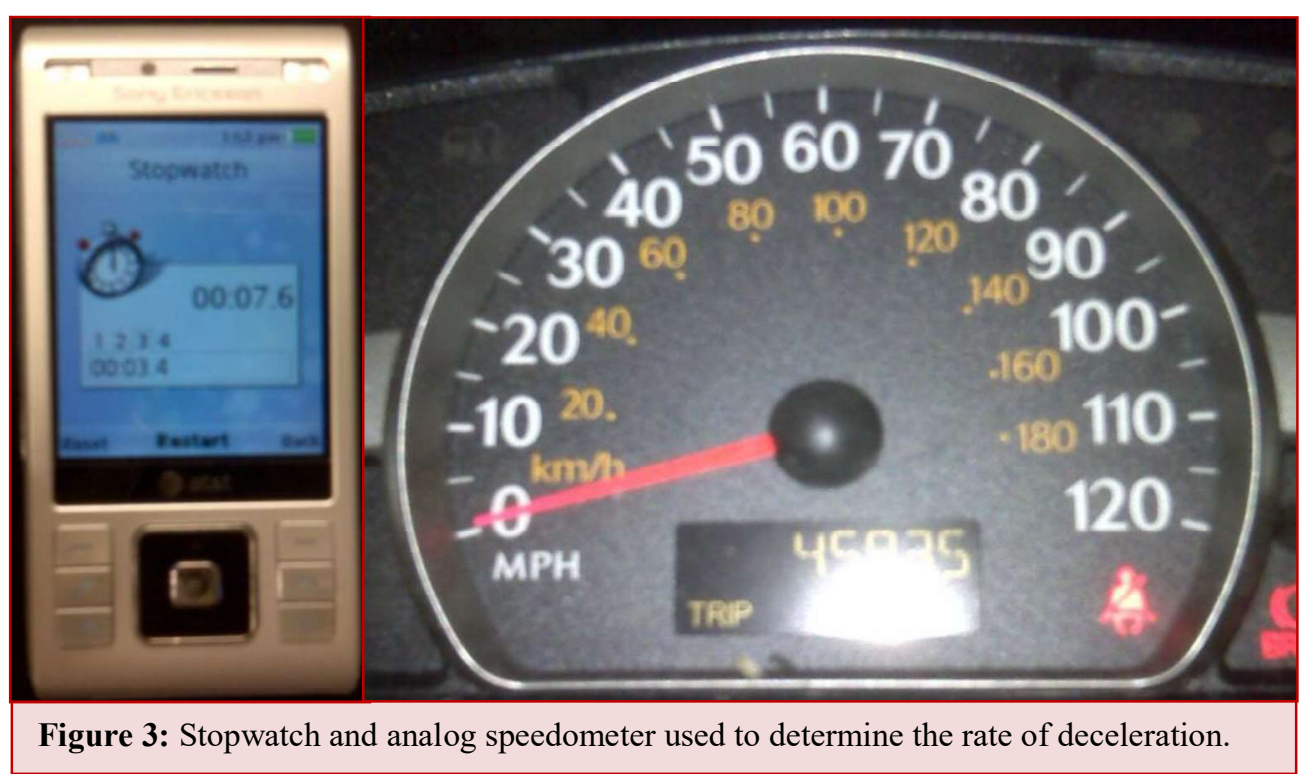


The force on the vehicle (R.C. Hibbler, 110), was calculated using

$$
F=m a .
$$

The mass in (3) was determined by adding the mass of the test driver to the mass of the vehicle which was given by the Saturn owner's manual (Saturn). Thus, the total mass of car and driver was

$$
m_{\text {total }}=m_{\text {vechicle }}+m_{\text {occupant }}=2,750 \text { lbs }+180 \text { lbs }=2,930 \text { lbs. . }
$$

From the force given in (3) and the test velocities, the power of the test car (Serway Jewett, 214) was found through the relationship

$$
P=F v
$$

For automobiles, the most common unit of power is horsepower (What is Horsepower?). Note that one unit of horsepower is approximately

$$
1 h p \approx 17,695.7 \frac{f t^{2} l b s}{s^{3}} .
$$

Putting everything together, we determined the horsepower over time for the test vehicle under various tire pressures.

\section{DISCUSSION}

The 'Velocity vs Time' graph for each tire pressure (Appendix B - Chart 1) shows the steadily decreasing amount of time it took to deccelerate given lower tire pressures. Notice the relatively flatter slope for all the lines in the $45-40 \mathrm{mph}$ velocity zone. This can be attributed to a slight downhill grade going onto a bridge on the roadway used for testing. The momentary downhill slope is also reflected by the flucations in the chart of the 'Horsepower vs Velocity' 
(Chart 2 - Appendix B). Accounting for changes in the test track, we interpolate the average trial velocities for each tire pressure using a $5^{\text {th }}$ order polynomial. For instance, the average velocities over three trials using 20 psi (Appendix A - Table 1) were found to be:

\begin{tabular}{|c|ccccccc|}
\cline { 2 - 8 } \multicolumn{1}{c|}{} & \multicolumn{6}{c|}{ Mean Measured Times at Set Velocities - 20 psi } \\
\hline Velocity $(\mathrm{mph})$ & 50 & 45 & 40 & 35 & 30 & 25 & 20 \\
Velocity $(\mathrm{ft} / \mathrm{s})$ & 77.3 & 66 & 58.7 & 51.3 & 44 & 36.7 & 29.3 \\
\hline Time $(s)$ & 0.00 & 7.80 & 17.67 & 28.40 & 37.70 & 49.93 & 63.20 \\
\hline
\end{tabular}

Note that all units were first standardized in terms of feet and seconds. Microsoft Excel interpoloated the converted velocities as

$$
v(t)=73.3585-1.2204 t+0.0462 t^{2}-0.0018 t^{3}+3.2 E^{-05} t^{4}-1.9 E^{-07} t^{5} .
$$

Using equation (7) with (1) we found the interpolated acceleration to be

$$
a(t)=\frac{d v}{d t}=-1.2204+0.0924 t-0.0054 t^{2}+1.28 E^{-04} t^{3}-9.6 E^{-07} t^{4}
$$

and from (2) the interpolated displacement was

$$
\begin{aligned}
d(t)=\int_{0}^{t} v(s) d s= & 73.3585 t-0.6102 t^{2}+0.0154 t^{3} \\
& -0.00046 t^{4}+6.3 E^{-06} t^{5}-3.19 E^{-08} t^{6}
\end{aligned}
$$

Using the total test time for the 20 psi test, we can estitmate the total distance traveled during the 20 psi test as

$$
d(63.2)=3,120.8 f t
$$

which corresponds with Table 8 in Appendix A. The remaining trials were similarly analysized and their values are summarized in Tables $2-8$ found in Appendix A. 
The 'Horsepower vs Velocity' chart (Appendix B - Chart 2) shows the amount of horsepower acting against the coasting car. Viewed another way, this chart indicates the amount of horsepower needed to maintain the indicated velocity. The negative horsepower is a reflection of wind resistence on the car and friction between the tires and the pavement. Comparing the horsepower values for each tire pressure (Appendix B - Chart 3), it is clear that the lower pressures require more horsepower to maintain a constant velocity than the higher pressures.

\section{CONCLUSION AND RECOMMENDATIONS}

All of the results from this project pointed to the fact that there is a relationship between lower tire pressures and lower efficiency. The increased horsepower consumption will be most noticable at higher speeds as is indicated in Chart 3 of Appendix B. For instance, at $50 \mathrm{mph}$ the 50 psi tires required $11.37 \mathrm{hp}$ to maintain a constant velocity while the $20 \mathrm{psi}$ set required $14.82 \mathrm{hp}$ which was a suprising 30\% increase in required horsepower. At $20 \mathrm{mph}$, all the horsepower discrepencies were negligable as all he values fell between $3.405 \pm 0.705 \mathrm{hp}$.

Variances in the slower velocities can also be attributed to the road condions of the test track. At 50 psi the test car breached the $20 \mathrm{mph}$ threshold 4,108.8 feet from the starting line while breaching the same threshold 3,120.8 feet from the starting line under 20 psi. The grade of the road was influencing the calculated horsepowers differently at these two positions. The problem may be avoided in future experiments by recording the velocities at fixed road markers to ensure all measurements are taken under identical road conditions. Also, it is recommend that future research incorporate the use of a more accurate digital speedometer. Using an analog speedometer meant trusting the eye to accurately guage the moment when the needle passed the specified limits. 


\section{NOMENCLATURE}

\begin{tabular}{|cll|}
\hline Symbol & Description & Unit \\
\hline$F$ & Force & $\mathrm{ft} \cdot \mathrm{lbs} / \mathrm{s}^{2}$ \\
\hline$m$ & Mass & $\mathrm{lbs}$ \\
\hline$m p h$ & Miles per hour & $\mathrm{miles} / \mathrm{hour}$ \\
\hline$P$ & Power & $\mathrm{ft} \cdot \mathrm{lbs} / \mathrm{s}$ and $\mathrm{Hp}$ \\
\hline$p s i$ & Pounds per square inch & $\mathrm{lbs} / \mathrm{in}^{2}$ \\
\hline$s$ & Position & $\mathrm{ft}$ \\
\hline$v$ or $V e l$ & Velocity & $\mathrm{ft} / \mathrm{s}$ and $\mathrm{mph}$ \\
\hline$a$ or $A c c$ & Acceleration & $\mathrm{ft} / \mathrm{s}^{2}$ \\
\hline$\Delta v$ & Change in velocity & $\mathrm{ft} / \mathrm{s}$ \\
\hline$\Delta s$ & Displacement & $\mathrm{ft}$ \\
\hline$\Delta t$ & Change in time & $s$ \\
\hline
\end{tabular}

\section{REFERENCES}

2004 Saturn Ion Owners Manual. Lithio: 2003.

Hibbeler, R.. Engineering Mechanics Dynmaics . Upper Saddle River: Prentice Hall, 2010.

Serway, and Jewett Physics for Scientists and Engineers. Belmont: Thomson, 2008.

"What is Horsepower?". Web cars. 5-6-10<http://www.web-cars.com/math/horsepower.html>. 


\section{APPENDIX A - TABLES}

\begin{tabular}{|c|c|c|c|c|c|c|c|c|}
\hline Pressure & Trial & $50 \mathrm{mph}$ & $45 \mathrm{mph}$ & $40 \mathrm{mph}$ & $35 \mathrm{mph}$ & $30 \mathrm{mph}$ & $25 \mathrm{mph}$ & $20 \mathrm{mph}$ \\
\hline \multirow{4}{*}{50 psi } & 1 & 0.0 & 10.3 & 24.8 & 35.6 & 48.8 & 66.7 & 87.9 \\
\hline & 2 & 0.0 & 9.2 & 23.5 & 33.2 & 46.2 & 62.7 & 81.8 \\
\hline & 3 & 0.0 & 9.5 & 23.5 & 33.0 & 47.5 & 62.6 & 84.1 \\
\hline & Mean & 0.00 & 9.67 & 23.93 & 33.93 & 47.50 & 64.00 & 84.60 \\
\hline \multirow{4}{*}{45 psi } & 1 & 0.0 & 9.8 & 25.3 & 35.9 & 48.5 & 66.6 & 86.1 \\
\hline & 2 & 0.0 & 10.2 & 24.8 & 35.9 & 50.2 & 68.8 & 86.2 \\
\hline & 3 & 0.0 & 9.6 & 23.4 & 32.7 & 46.0 & 62.2 & 80.4 \\
\hline & Mean & 0.00 & 9.87 & 24.50 & 34.83 & 48.23 & 65.87 & 84.23 \\
\hline \multirow{4}{*}{40 psi } & 1 & 0.0 & 9.0 & 22.6 & 34.3 & 46.0 & 61.3 & 83.3 \\
\hline & 2 & 0.0 & 9.2 & 21.2 & 33.1 & 44.4 & 58.1 & 78.8 \\
\hline & 3 & 0.0 & 9.1 & 22.0 & 31.5 & 44.4 & 58.1 & 78.0 \\
\hline & Mean & 0.00 & 9.10 & 21.93 & 32.97 & 44.93 & 59.17 & 80.03 \\
\hline \multirow{4}{*}{35 psi } & 1 & 0.0 & 9.0 & 21.6 & 30.1 & 41.5 & 55.7 & 75.5 \\
\hline & 2 & 0.0 & 8.7 & 21.3 & 31.0 & 41.7 & 55.7 & 74.3 \\
\hline & 3 & 0.0 & 9.1 & 21.6 & 31.9 & 43.2 & 58.3 & 77.3 \\
\hline & Mean & 0.00 & 8.93 & 21.50 & 31.00 & 42.13 & 56.57 & 75.70 \\
\hline \multirow{4}{*}{$30 \mathrm{psi}$} & 1 & 0.0 & 8.0 & 20.9 & 30.8 & 41.6 & 55.2 & 72.5 \\
\hline & 2 & 0.0 & 8.3 & 20.0 & 31.2 & 41.6 & 54.6 & 72.0 \\
\hline & 3 & 0.0 & 8.7 & 21.6 & 31.3 & 41.7 & 57.2 & 75.7 \\
\hline & Mean & 0.00 & 8.33 & 20.83 & 31.10 & 41.63 & 55.67 & 73.40 \\
\hline \multirow{4}{*}{25 psi } & 1 & 0.0 & 8.3 & 18.9 & 30.1 & 38.8 & 51.3 & 65.8 \\
\hline & 2 & 0.0 & 8.2 & 19.8 & 30.2 & 39.5 & 52.7 & 69.6 \\
\hline & 3 & 0.0 & 8.1 & 19.5 & 31.5 & 41.9 & 55.6 & 72.6 \\
\hline & Mean & 0.00 & 8.20 & 19.40 & 30.60 & 40.07 & 53.20 & 69.33 \\
\hline \multirow{4}{*}{20 psi } & 1 & 0.0 & 7.9 & 17.7 & 29.0 & 37.4 & 49.1 & 61.9 \\
\hline & 2 & 0.0 & 7.9 & 17.8 & 28.1 & 38.1 & 50.1 & 63.0 \\
\hline & 3 & 0.0 & 7.6 & 17.5 & 28.1 & 37.6 & 50.6 & 64.7 \\
\hline & Mean & 0.00 & 7.80 & 17.67 & 28.40 & 37.70 & 49.93 & 63.20 \\
\hline
\end{tabular}

Table 1: Under various tire pressures, this table lists the number of seconds it took the test car to reach $5 \mathrm{mph}$ speed thresholds after coasting from $50 \mathrm{mph}$. 


\begin{tabular}{|c|c|c|c|c|c|c|c|c|}
\hline \multicolumn{9}{|c|}{50 psi - Test Statistics } \\
\hline \multirow{3}{*}{ 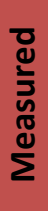 } & \multirow{3}{*}{$\begin{array}{l}\text { Mean Time (s): } \\
\text { Velocity (mph): } \\
\text { Velocity }(\mathrm{ft} / \mathrm{s}):\end{array}$} & 0.00 & 9.67 & 23.93 & 33.93 & 47.50 & 64.00 & 84.60 \\
\hline & & 50.00 & 45.00 & 40.00 & 35.00 & 30.00 & 25.00 & 20.00 \\
\hline & & 73.33 & 66.00 & 58.67 & 51.33 & 44.00 & 36.67 & 29.33 \\
\hline \multirow{3}{*}{ 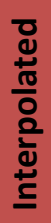 } & \multirow{3}{*}{$\begin{array}{l}\text { Velocity }(\mathrm{ft} / \mathrm{s}) \text { : } \\
\text { Acceleration }\left(\mathrm{ft} / \mathrm{s}^{2}\right) \text { : } \\
\text { Displacement }(\mathrm{ft}) \text { : }\end{array}$} & 73.28 & 66.21 & 58.12 & 51.97 & 43.69 & 36.75 & 29.32 \\
\hline & & -0.9370 & -0.5973 & -0.5874 & -0.6338 & -0.5523 & -0.2905 & -0.7320 \\
\hline & & 0.0 & 671.8 & 1558.3 & 2109.1 & 2756.9 & 3414.3 & 4108.8 \\
\hline \multirow{3}{*}{$\frac{\substack{\frac{\pi}{\pi} \\
\frac{\pi}{3}}}{\frac{U}{J}}$} & \multirow{3}{*}{$\begin{array}{r}\text { Force }\left(\mathrm{ft} \mathrm{lbs} / \mathrm{s}^{2}\right) \text { : } \\
\text { Power }\left(\mathrm{ft}^{2} \mathrm{lbs} / \mathrm{s}^{3}\right) \text { : } \\
\text { Power }(\mathrm{HP}) \text { : }\end{array}$} & -2745.5 & -1750.1 & -1721.1 & -1856.9 & -1618.3 & -851.2 & -2144.6 \\
\hline & & -201179 & -115877 & -100023 & -96499 & -70708 & -31278 & -62887 \\
\hline & & -11.37 & -6.55 & -5.65 & -5.45 & -4.00 & -1.77 & -3.55 \\
\hline
\end{tabular}

Table 2: Measured, Interpolated and Calculated values for the experiment with the tires inflated to 50 psi.

\begin{tabular}{|c|c|c|c|c|c|c|c|c|}
\hline \multicolumn{9}{|c|}{45 psi - Test Statistics } \\
\hline \multirow{3}{*}{ 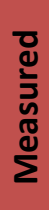 } & Mean Time (s): & 0.00 & 9.87 & 24.50 & 34.83 & 48.23 & 65.87 & 84.23 \\
\hline & Velocity (mph): & 50.00 & 45.00 & 40.00 & 35.00 & 30.00 & 25.00 & 20.00 \\
\hline & Velocity (ft/s): & 73.33 & 66.00 & 58.67 & 51.33 & 44.00 & 36.67 & 29.33 \\
\hline \multirow{3}{*}{ 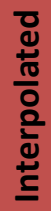 } & Velocity $(\mathrm{ft} / \mathrm{s})$ : & 73.29 & 66.18 & 58.20 & 51.88 & 43.73 & 36.73 & 29.33 \\
\hline & Acceleration $\left(\mathrm{ft} / \mathrm{s}^{2}\right)$ : & -0.9584 & -0.5701 & -0.5767 & -0.6355 & -0.5445 & -0.2662 & -0.8395 \\
\hline & Displacement (ft): & 0.0 & 685.2 & 1595.3 & 2164.4 & 2803.7 & 3505.7 & 4127.1 \\
\hline \multirow{3}{*}{$\begin{array}{l}\text { D্d } \\
\frac{\mathbb{\pi}}{\bar{J}} \\
\frac{\mathrm{U}}{\mathrm{J}}\end{array}$} & Force $\left(\mathrm{ft} \mathrm{lbs} / \mathrm{s}^{2}\right)$ : & -2808.2 & -1670.3 & -1689.8 & -1862.0 & -1595.3 & -779.9 & -2459.6 \\
\hline & Power $\left(\mathrm{ft}^{2} \mathrm{lbs} / \mathrm{s}^{3}\right)$ : & -205811 & -110531 & -98352 & -96603 & -69761 & -28647 & -72128 \\
\hline & Power (HP): & -11.63 & -6.25 & -5.56 & -5.46 & -3.94 & -1.62 & -4.08 \\
\hline
\end{tabular}

Table 3: Measured, Interpolated and Calculated values for the experiment with the tires inflated to 45 psi. 


\begin{tabular}{|c|c|c|c|c|c|c|c|c|}
\hline \multicolumn{9}{|c|}{40 psi - Test Statistics } \\
\hline \multirow{3}{*}{ 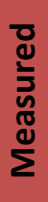 } & \multirow{3}{*}{$\begin{array}{l}\text { Mean Time }(\mathrm{s}) \text { : } \\
\text { Velocity }(\mathrm{mph}): \\
\text { Velocity }(\mathrm{ft} / \mathrm{s}) \text { : }\end{array}$} & 0.00 & 9.10 & 21.93 & 32.97 & 44.93 & 59.17 & 80.03 \\
\hline & & 50.00 & 45.00 & 40.00 & 35.00 & 30.00 & 25.00 & 20.00 \\
\hline & & 73.33 & 66.00 & 58.67 & 51.33 & 44.00 & 36.67 & 29.33 \\
\hline \multirow{3}{*}{ 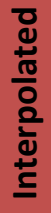 } & \multirow{3}{*}{$\begin{array}{l}\text { Velocity }(\mathrm{ft} / \mathrm{s}) \text { : } \\
\text { Acceleration }\left(\mathrm{ft} / \mathrm{s}^{2}\right) \text { : } \\
\text { Displacement }(\mathrm{ft}) \text { : }\end{array}$} & 73.31 & 66.08 & 58.48 & 51.56 & 43.87 & 36.70 & 29.33 \\
\hline & & -1.0188 & -0.6431 & -0.5950 & -0.6531 & -0.6057 & -0.3875 & -0.5552 \\
\hline & & 0.0 & 631.7 & 1430.2 & 2038.2 & 2608.3 & 3178.2 & 3871.4 \\
\hline \multirow{3}{*}{$\frac{\text { D্d }}{\frac{\pi}{3}}$} & \multirow{3}{*}{$\begin{array}{r}\text { Force }\left(\mathrm{ft} \mathrm{lbs} / \mathrm{s}^{2}\right) \text { : } \\
\text { Power }\left(\mathrm{ft}^{2} \mathrm{lbs} / \mathrm{s}^{3}\right) \text { : } \\
\text { Power (HP): }\end{array}$} & -2985.0 & -1884.3 & -1743.4 & -1913.7 & -1774.7 & -1135.2 & -1626.7 \\
\hline & & -218837 & -124513 & -101959 & -98666 & -77856 & -41663 & -47712 \\
\hline & & -12.37 & -7.04 & -5.76 & -5.58 & -4.40 & -2.35 & -2.70 \\
\hline
\end{tabular}

Table 4: Measured, Interpolated and Calculated values for the experiment with the tires inflated to 40 psi.

\begin{tabular}{|c|c|c|c|c|c|c|c|c|}
\hline \multicolumn{9}{|c|}{35 psi - Test Statistics } \\
\hline \multirow{3}{*}{ 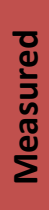 } & Mean Time (s): & 0.00 & 8.93 & 21.50 & 31.00 & 42.13 & 56.57 & 75.70 \\
\hline & Velocity (mph): & 50.00 & 45.00 & 40.00 & 35.00 & 30.00 & 25.00 & 20.00 \\
\hline & Velocity (ft/s): & 73.33 & 66.00 & 58.67 & 51.33 & 44.00 & 36.67 & 29.33 \\
\hline \multirow{3}{*}{ 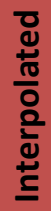 } & Velocity $(\mathrm{ft} / \mathrm{s})$ : & 73.30 & 66.12 & 58.36 & 51.70 & 43.80 & 36.71 & 29.33 \\
\hline & Acceleration $\left(\mathrm{ft} / \mathrm{s}^{2}\right)$ : & -1.0703 & -0.6391 & -0.6553 & -0.7325 & -0.6499 & -0.3248 & -0.8440 \\
\hline & Displacement (ft): & 0.0 & 619.7 & 1402.4 & 1925.9 & 2456.5 & 3032.0 & 3677.5 \\
\hline \multirow{3}{*}{$\begin{array}{l}\text { D্d } \\
\frac{\mathbb{\pi}}{\bar{J}} \\
\frac{\mathrm{U}}{\mathrm{J}}\end{array}$} & Force $\left(\mathrm{ft} \mathrm{lbs} / \mathrm{s}^{2}\right)$ : & -3136.1 & -1872.7 & -1920.1 & -2146.1 & -1904.3 & -951.6 & -2472.9 \\
\hline & Power $\left(\mathrm{ft}^{2} \mathrm{lbs} / \mathrm{s}^{3}\right)$ : & -229891 & -123816 & -112061 & -110964 & -83414 & -34937 & -72528 \\
\hline & Power (HP): & -12.99 & -7.00 & -6.33 & -6.27 & -4.71 & -1.97 & -4.10 \\
\hline
\end{tabular}

Table 5: Measured, Interpolated and Calculated values for the experiment with the tires inflated to 35 psi. 


\begin{tabular}{|c|c|c|c|c|c|c|c|c|}
\hline \multicolumn{9}{|c|}{30 psi - Test Statistics } \\
\hline \multirow{3}{*}{ 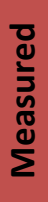 } & \multirow{3}{*}{$\begin{array}{l}\text { Mean Time }(\mathrm{s}) \text { : } \\
\text { Velocity }(\mathrm{mph}): \\
\text { Velocity }(\mathrm{ft} / \mathrm{s}) \text { : }\end{array}$} & 0.00 & 8.33 & 20.83 & 31.10 & 41.63 & 55.67 & 73.40 \\
\hline & & 50.00 & 45.00 & 40.00 & 35.00 & 30.00 & 25.00 & 20.00 \\
\hline & & 73.33 & 66.00 & 58.67 & 51.33 & 44.00 & 36.67 & 29.33 \\
\hline \multirow{3}{*}{ 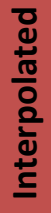 } & \multirow{3}{*}{$\begin{array}{l}\text { Velocity }(\mathrm{ft} / \mathrm{s}) \text { : } \\
\text { Acceleration }\left(\mathrm{ft} / \mathrm{s}^{2}\right) \text { : } \\
\text { Displacement }(\mathrm{ft}) \text { : }\end{array}$} & 73.32 & 66.05 & 58.55 & 51.48 & 43.91 & 36.69 & 29.33 \\
\hline & & -1.1986 & -0.6571 & -0.6283 & -0.7333 & -0.6676 & -0.3532 & -0.8453 \\
\hline & & 0.0 & 577.4 & 1356.0 & 1921.9 & 2423.6 & 2984.0 & 3580.6 \\
\hline \multirow{3}{*}{$\frac{\text { D্d }}{\frac{\pi}{3}}$} & \multirow{3}{*}{$\begin{array}{r}\text { Force }\left(\mathrm{ft} \mathrm{lbs} / \mathrm{s}^{2}\right) \text { : } \\
\text { Power }\left(\mathrm{ft}^{2} \mathrm{lbs} / \mathrm{s}^{3}\right) \text { : } \\
\text { Power (HP): }\end{array}$} & -3511.9 & -1925.2 & -1840.8 & -2148.5 & -1956.1 & -1034.9 & -2476.6 \\
\hline & & -257496 & -127158 & -107780 & -110613 & -85895 & -37967 & -72643 \\
\hline & & -14.55 & -7.19 & -6.09 & -6.25 & -4.85 & -2.15 & -4.11 \\
\hline
\end{tabular}

Table 6: Measured, Interpolated and Calculated values for the experiment with the tires inflated to 30 psi.

\begin{tabular}{|c|c|c|c|c|c|c|c|c|}
\hline \multicolumn{9}{|c|}{25 psi - Test Statistics } \\
\hline \multirow{3}{*}{ 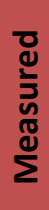 } & Mean Time (s): & 0.00 & 8.20 & 19.40 & 30.60 & 40.07 & 53.20 & 69.33 \\
\hline & Velocity (mph): & 50.00 & 45.00 & 40.00 & 35.00 & 30.00 & 25.00 & 20.00 \\
\hline & Velocity (ft/s): & 73.33 & 66.00 & 58.67 & 51.33 & 44.00 & 36.67 & 29.33 \\
\hline \multirow{3}{*}{ 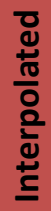 } & Velocity $(\mathrm{ft} / \mathrm{s})$ : & 73.36 & 65.91 & 58.86 & 51.08 & 44.17 & 36.63 & 29.34 \\
\hline & Acceleration $\left(\mathrm{ft} / \mathrm{s}^{2}\right)$ : & -1.2235 & -0.6960 & -0.6372 & -0.7391 & -0.6940 & -0.4430 & -0.7075 \\
\hline & Displacement (ft): & 0.0 & 568.1 & 1266.3 & 1883.0 & 2333.7 & 2860.4 & 3397.2 \\
\hline \multirow{3}{*}{$\begin{array}{l}\text { D্d } \\
\frac{\mathbb{\pi}}{\bar{J}} \\
\frac{\mathrm{U}}{\mathrm{J}}\end{array}$} & Force $\left(\mathrm{ft} \mathrm{lbs} / \mathrm{s}^{2}\right)$ : & -3584.8 & -2039.2 & -1867.1 & -2165.5 & -2033.5 & -1298.0 & -2072.9 \\
\hline & Power $\left(\mathrm{ft}^{2} \mathrm{lbs} / \mathrm{s}^{3}\right)$ : & -262967 & -134407 & -109886 & -110616 & -89815 & -47541 & -60814 \\
\hline & Power (HP): & -14.86 & -7.60 & -6.21 & -6.25 & -5.08 & -2.69 & -3.44 \\
\hline
\end{tabular}

Table 7: Measured, Interpolated and Calculated values for the experiment with the tires inflated to 25 psi. 


\begin{tabular}{|c|c|c|c|c|c|c|c|c|}
\hline \multicolumn{9}{|c|}{20 psi - Test Statistics } \\
\hline \multirow{3}{*}{ 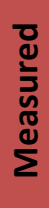 } & Mean Time (s): & 0.00 & 7.80 & 17.67 & 28.40 & 37.70 & 49.93 & 63.20 \\
\hline & Velocity (mph): & 50.00 & 45.00 & 40.00 & 35.00 & 30.00 & 25.00 & 20.00 \\
\hline & Velocity (ft/s): & 73.33 & 66.00 & 58.67 & 51.33 & 44.00 & 36.67 & 29.33 \\
\hline \multirow{3}{*}{ 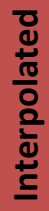 } & Velocity (ft/s): & 73.36 & 65.89 & 58.88 & 51.07 & 44.18 & 36.62 & 29.34 \\
\hline & Acceleration $\left(\mathrm{ft} / \mathrm{s}^{2}\right)$ : & -1.2204 & -0.7769 & -0.6974 & -0.7532 & -0.7071 & -0.5280 & -0.7156 \\
\hline & Displacement (ft): & 0.0 & 540.9 & 1156.0 & 1746.5 & 2189.0 & 2680.8 & 3120.8 \\
\hline \multirow{3}{*}{$\begin{array}{l}\text { D্d } \\
\frac{\pi}{T} \\
\frac{0}{3} \\
\frac{0}{\pi}\end{array}$} & Force $\left(\mathrm{ft} \mathrm{lbs} / \mathrm{s}^{2}\right)$ : & -3575.8 & -2276.4 & -2043.3 & -2206.8 & -2071.7 & -1547.1 & -2096.8 \\
\hline & Power $\left(\mathrm{ft}^{2} \mathrm{lbs} / \mathrm{s}^{3}\right)$ : & -262313 & -150001 & -120307 & -112695 & -91523 & -56650 & -61520 \\
\hline & Power (HP): & -14.82 & -8.48 & -6.80 & -6.37 & -5.17 & -3.20 & -3.48 \\
\hline
\end{tabular}

Table 8: Measured, Interpolated and Calculated values for the experiment with the tires inflated to 20 psi. 


\section{APPENDIX B - CHARTS}

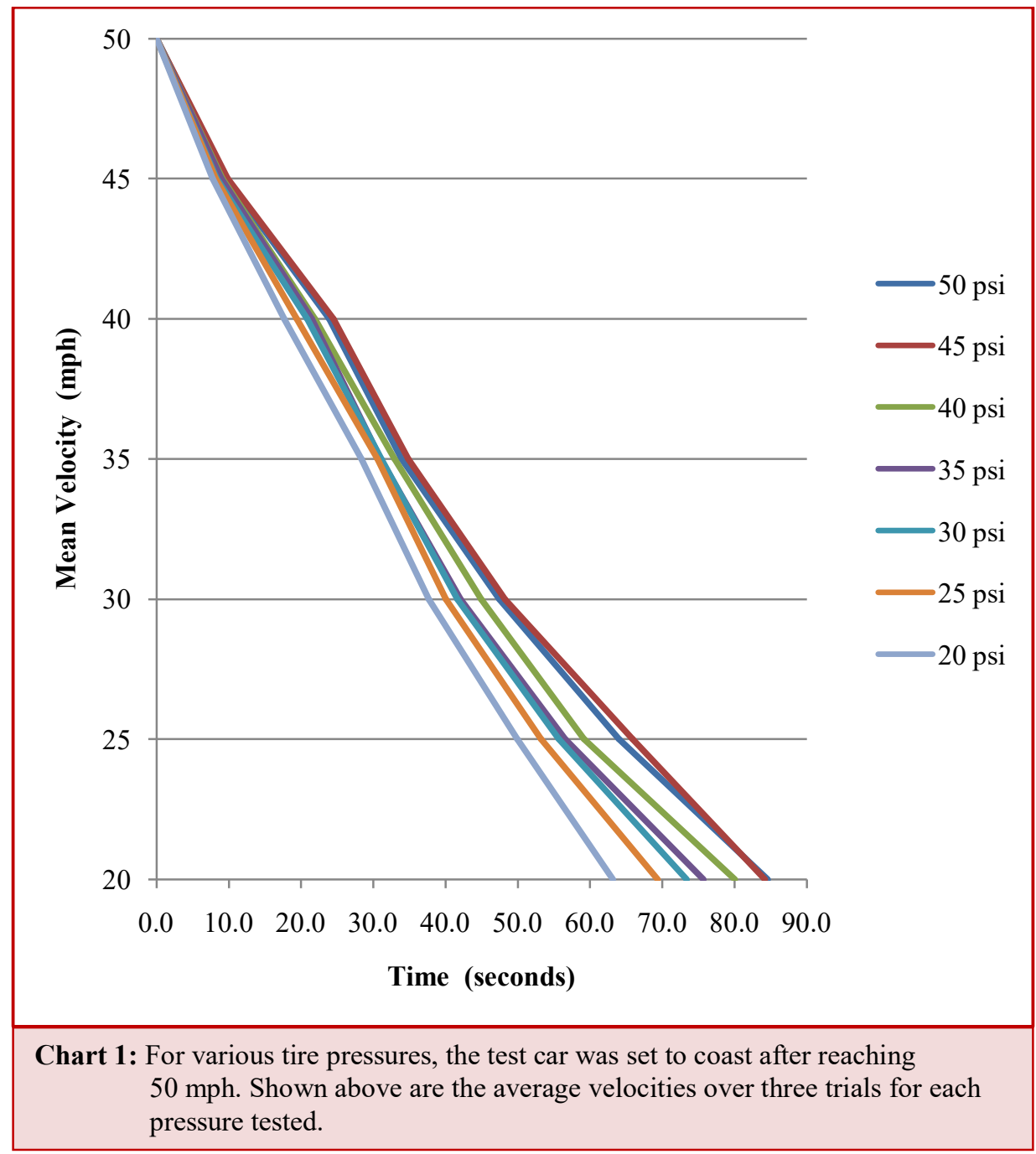




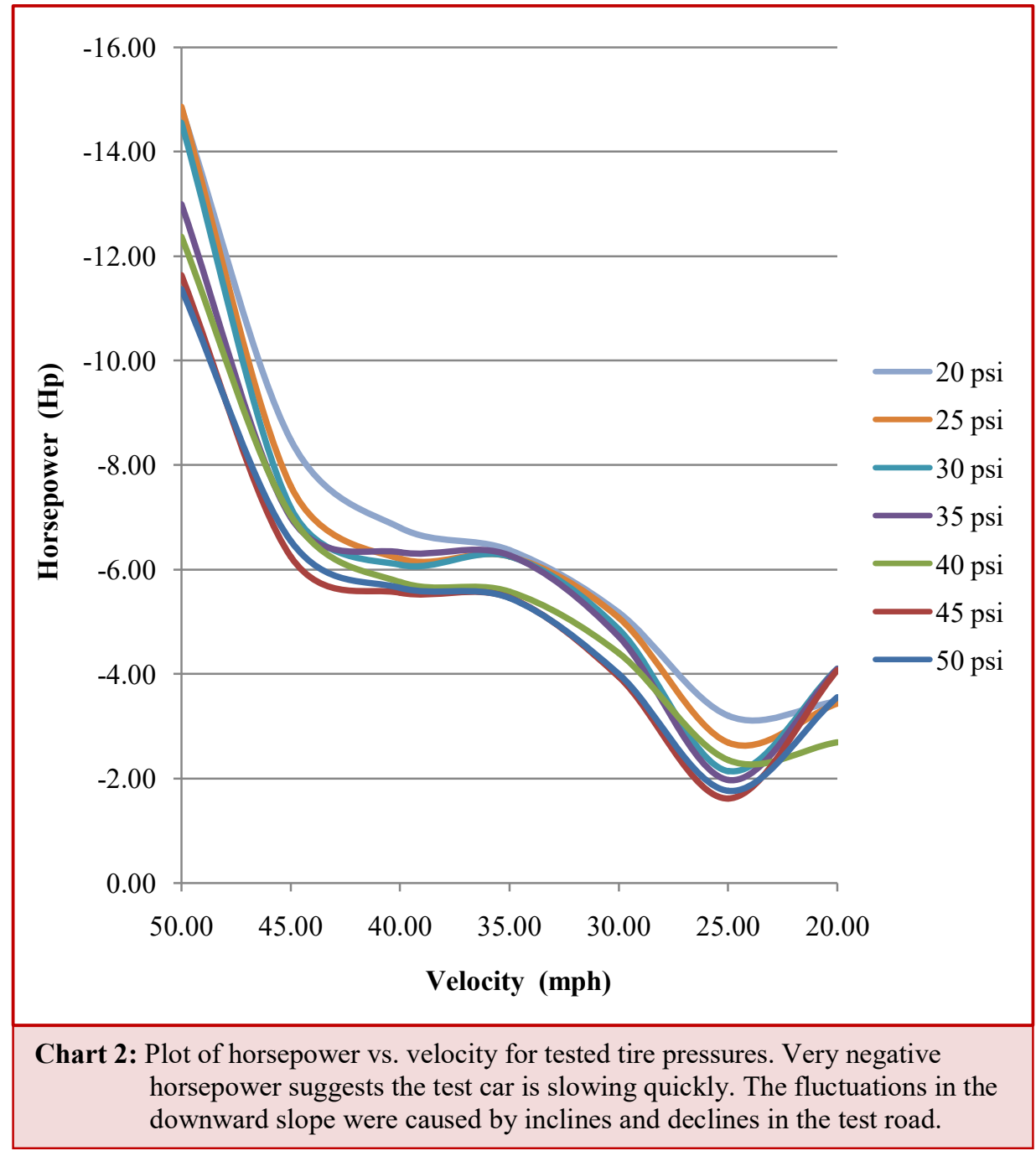




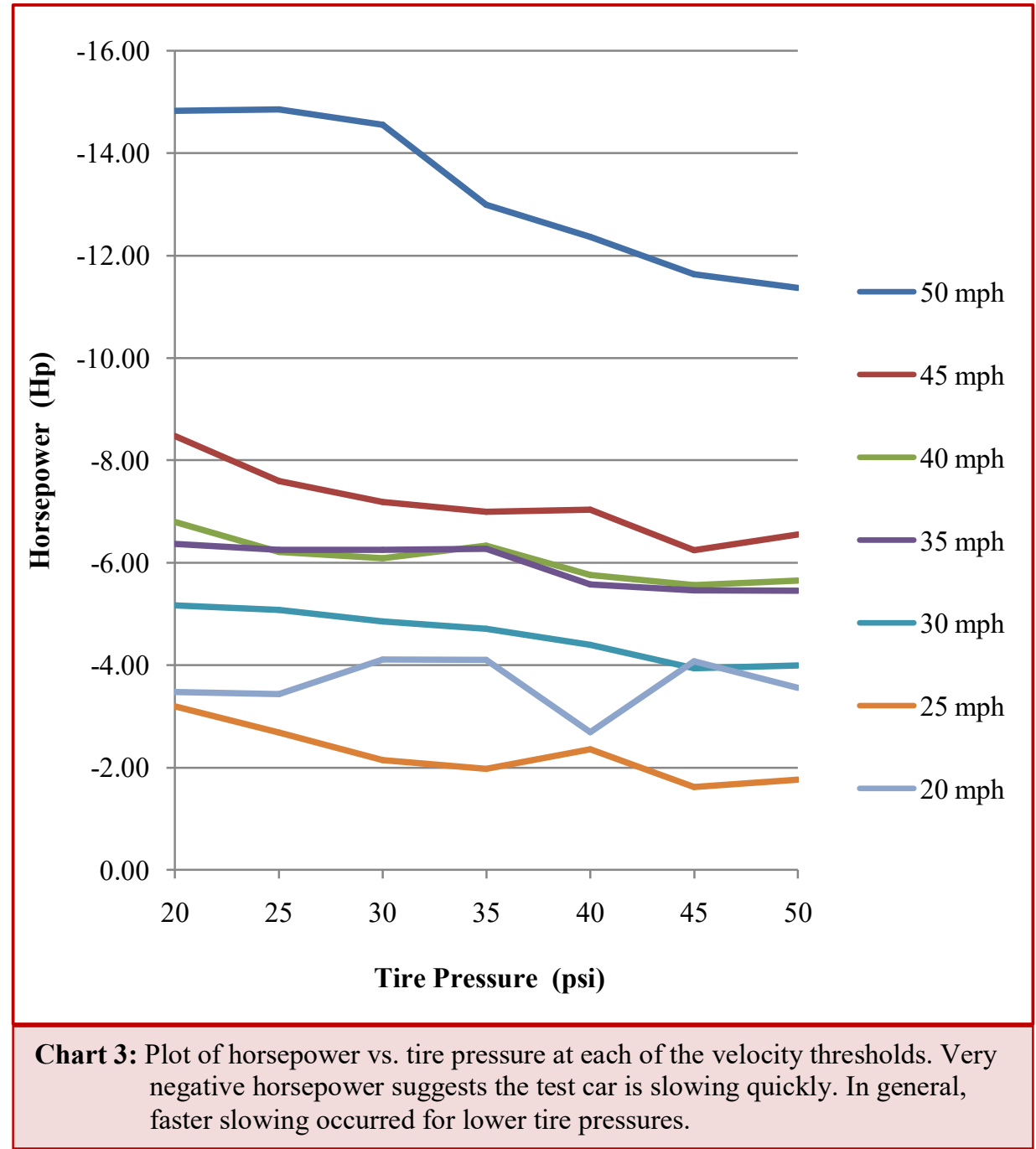

